\title{
Hyperparasitoids (Hymenoptera: Encyrtidae and Signiphoridae) of Hypogeococcus spp. mealybugs (Hemiptera: Pseudococcidae) in Argentina and Paraguay
}

Hiperparasitoides (Hymenoptera: Encyrtidae y Signiphoridae) de cochinillas Hypogeococcus spp. (Hemiptera: Pseudococcidae) en Argentina y Paraguay

Serguei V. Triapitsyn1, María B. Aguirre²*, Guillermo A. Logarzo², Stephen D. Hight ${ }^{3}$

1 Entomology Research Museum, Department of Entomology, University of California, Riverside, California, 92521, USA.

2 FuEDEI, Simón Bolívar 1559, Hurlingham, Buenos Aires, Argentina.

3 USDA-ARS, 6383 Mahan Dr., Tallahassee, Florida, 32308, USA.

*Corresponding author. Email: redbell_@hotmail.com

\begin{abstract}
Identified and reviewed taxonomically are the hyperparasitoids (Hymenoptera: Chalcidoidea) in Argentina and Paraguay associated with Hypogeococcus spp. (Hemiptera: Pseudococcidae), mealybugs that feed on various native cacti (Cactaceae) as well as some Amaranthaceae and Portulacaceae. The following genera and species were collected and reared in the course of surveys conducted in Argentina during 2010-2019 and in Paraguay during 2016-2019: Chartocerus argentinus (Brèthes) stat. rev. [reinstated as a valid species from the previous synonymy with Chartocerus niger (Ashmead)] and Chartocerus axillaris De Santis from Argentina (Signiphoridae), an undescribed Cheiloneurus sp. from Paraguay and Prochiloneurus argentinensis (De Santis) from Argentina (Encyrtidae). These are secondary parasitoids via Encyrtidae primary parasitoids of Hypogeococcus sp., candidate biological control agents against a Hypogeococcus sp. (commonly called the Harrisia cactus mealybug) that is devastating the native columnar cacti in Puerto Rico. The previously unknown male
\end{abstract}

Ref. bibliográfica: Triapitsyn, S. V.; Aguirre, M. B.; Logarzo, G. A.; Hight, S. D. 2020. “Hyperparasitoids (Hymenoptera: Encyrtidae and Signiphoridae) of Hypogeococcus spp. mealybugs (Hemiptera: Pseudococcidae) in Argentina and Paraguay". Acta zoológica lilloana 64 (2): 148-165. Fundación Miguel Lillo, Tucumán, Argentina. D.O.I.: https://doi.org/10.30550/j.azl/2020.64.2/5

> Recibido: 23 de julio 2020 - Aceptado: 10 de noviembre 2020.

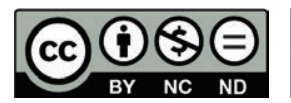


of Chartocerus argentinus is described, and a lectotype is designated for Signiphora argentina Brèthes. Taxonomic notes are provided for Ablerus platensis (Brèthes) (Hymenoptera: Azotidae), for which a lectotype is designated (for Dimacrocerus platensis Brèthes); it is newly recorded from Paraguay. Hyperparasitoids can be detrimental to biological control programs, but their impact has often been unknown or underestimated. Taxonomic identification of the hyperparasitoids is the first step in assessing the potential negative impact to the natural control of Hypogeococcus spp. in South America.

Keywords - Mealybug, Chartocerus, Cheiloneurus, Prochiloneurus, taxonomic notes.

\section{RESUMEN}

Se presenta una revisión taxonómica de los hiperparasitoides identificados (Hymenoptera: Chalcidoidea) asociados a Hypogeococcus spp. (Hemiptera: Pseudococcidae), cochinillas que se alimentan de diversas cactáceas nativas (Cactaceae) y también de algunas Amaranthaceae y Portulacaceae. Los siguientes géneros y especies fueron recogidos y criados en el curso de estudios realizados en Argentina durante 2010-2019 y en Paraguay durante 2016-2019: Chartocerus argentinus (Brèthes) stat. rev. [reinstalado como una especie válida de la sinonimia previa con Chartocerus niger (Ashmead)] y Chartocerus axillaris De Santis de Argentina (Signiphoridae), una especie no descrita, Cheiloneurus sp., de Paraguay y Prochiloneurus argentinensis (De Santis) de Argentina (Encyrtidae). Estos son parasitoides secundarios a través de Encyrtidae parasitoides primarios de Hypogeococcus sp. que son potenciales candidatos para el control biológico de Hypogeococcus sp. (comúnmente llamada "cochinilla harinosa de los cactus") que está devastando a los cactus columnares nativos de Puerto Rico. Se describe el macho previamente desconocido de Chartocerus argentinus, y un lectotipo es designado para Signiphora argentina Brèthes. Se proporcionan notas taxonómicas para Ablerus platensis (Brèthes) (Hymenoptera: Azotidae), para el cual un lectotipo es designado (para Dimacrocerus platensis Brèthes); es un nuevo registro para Paraguay. Los hiperparasitoides pueden ser perjudiciales para los programas de control biológico, pero su impacto a menudo ha sido desconocido o subestimado. La identificación taxonómica de los hiperparasitoides es el primer paso para evaluar este impacto negativo potencial para el control natural de Hypogeococcus spp. en América del Sur.

Palabras clave - Cochinilla harinosa, Chartocerus, Cheiloneurus, Prochiloneurus, notas taxonómicas.

\section{INTRODUCTION}

Recent surveys were conducted in Argentina, Brazil, Paraguay and Puerto Rico (USA) for the natural enemies of the mealybugs Hypogeococcus spp. (Hemiptera: Pseudococcidae) that feed on many cacti (Cactaceae) and on some Amaranthaceae 
and Portulacaceae species. A complex of primary and secondary parasitoids in several families of Chalcidoidea (Hymenoptera) was revealed during these surveys, many of these natural enemies were described as new species (Triapitsyn, Aguirre, Logarzo, Dal Molin 2014a; Triapitsyn, Logarzo, Aguirre, Aquino, 2014b; Triapitsyn, Aguirre, Logarzo, 2016; Triapitsyn et al., 2018; Triapitsyn et al., 2020; Noyes and Triapitsyn, 2018). Two of the primary parasitoids, Anagyrus cachamai Triapitsyn, Logarzo and Aguirre and A. lapachosus Triapitsyn, Aguirre and Logarzo (Hymenoptera: Encyrtidae), both known from Argentina and Paraguay (Triapitsyn et al., 2018), are candidate biological control agents against a Puerto Rican pest Hypogeococcus sp., commonly called the "Harrisia cactus mealybug" (HCM). The HCM is devastating native columnar cacti in the dry forests of Puerto Rico and threatens cactus diversity on the adjacent Caribbean islands (Triapitsyn et al. 2018; Aguirre et al., 2019). Identification and current status of Hypogeococcus spp. in Argentina and elsewhere in the New World were discussed in Poveda-Martínez et al. (2019, 2020).

Triapitsyn et al. (2020) identified a complex of the secondary parasitoids of $H y$ pogeococcus spp. via their primary encyrtid parasitoids in Puerto Rico and estimated overall hyperparasitism to be around $10 \%$. They also commented that hyperparasitoids of Hypogeococcus spp. via the common primary parasitoids, Anagyrus spp., were also identified in Argentina (Triapitsyn et al., 2014a; Triapitsyn et al., 2018) but they appeared to be less diverse ( 2 different species in 2 genera in 2 families of Chalcidoidea) than in Puerto Rico (4 confirmed species in 3 genera in 3 chalcidoid families) (Triapitsyn et al., 2020). Moreover, one of the Argentine hyperparasitoids, Prochiloneurus argentinensis (De Santis) (Encyrtidae), was quite rare, and the other, Chartocerus axillaris De Santis (Signiphoridae), was common (Triapitsyn et al., 2014a; Triapitsyn et al., 2018, Triapitsyn et al., 2020). However, during our more recent 2019 surveys in Argentina and Paraguay for the natural enemies of Hypogeococcus spp., we reared and identified one additional genus and two more species of hyperparasitoids of these mealybugs, and also clarified host plant, mealybug, and primary parasitoid host associations of Chartocerus axillaris in Mendoza Province of Argentina. The relationships of these multi-trophic interactions are presented in this paper with taxonomic notes on some of the species. Currently, four different species in three genera in two families of Chalcidoidea (i.e., Encyrtidae and Signiphoridae) are now known in Argentina and Paraguay as hyperparasitoids of Hypogeococcus spp. via the encyrtid primary parasitoids.

Hyperparasitoids, which are commonly not host specific, can be detrimental to biological control programs in natural and agricultural settings (Tougeron and Tena, 2019). However, their impact has often been uninvestigated or underestimated. Taxonomic identification of the hyperparasitoids interacting in a multi-trophic system is the first step in assessing the potential negative impact they may have to the natural control of Hypogeococcus spp. on various native cacti and other host plants in South America. 


\section{MATERIALS AND METHODS}

Collecting and rearing.- Both primary and secondary parasitoids were collected in Argentina (mainly in northwestern provinces) during 2010-2019 and Paraguay during 2016-2019. Searches were conducted for parasitized Hypogeococcus spp. on their known host plants belonging to various Amaranthaceae, Cactaceae and Portulacaceae (Triapitsyn et al., 2014a; Triapitsyn et al., 2014b; Triapitsyn et al., 2018). When a Hypogeococcus sp. was detected, its nymphs and adults were collected with the plant material and placed in plastic containers of various sizes with screened lids and held under laboratory conditions for parasitoid emergence. Voucher specimens of the mealybug hosts were preserved in $95 \%$ ethanol and used for molecular and taxonomic identification in Argentina (Poveda-Martínez et al., 2019). The emerged adult parasitoids were collected with an aspirator and placed in $75-80 \%$ ethanol and kept in a freezer at $-20^{\circ} \mathrm{C}$ until they were used for identification by the first author. For the samples collected in Paraguay, we obtained a permission from the Dirección General de Protección y Conservación de la Biodiversidad de Vida Silvestre, Ministerio del Ambiente y Desarrollo Sostenible (Permit No. 090/2019). For the samples collected in Argentina, we obtained permissions from the Secretaría de Ambiente y Desarrollo Sustentable, Ministerio de Producción y Trabajo y Desarrollo Sustentable, Gobierno de Salta (Permit No. 0090227-267680-2017-0) and from the Dirección de Flora, Fauna Silvestre y Suelos, Gobierno de Tucumán (Permit No. 1785-330-2.018).

Identification and taxonomic studies. - Parasitoid specimens used in the taxonomic studies were critical point dried from ethanol and point-mounted. Selected specimens were then dissected and slide-mounted in Canada balsam, examined under a Zeiss Axioskop 2 plus compound microscope, and photographed using the Auto-Montage system. The photographs were retouched where necessary using Adobe Photoshop.

Acronyms for depositories of specimens are as follows: IBNP, Museo Nacional de Historia Natural del Paraguay, San Lorenzo, Paraguay; IMLA, Fundación e Instituto Miguel Lillo, San Miguel de Tucumán, Tucumán, Argentina; MACN, Museo Argentino de Ciencias Naturales "Bernardino Rivadavia", Buenos Aires, Argentina; UCRC, Entomology Research Museum, University of California, Riverside, California, USA; USNM, Systematic Entomology Laboratory, USDA-ARS, Smithsonian Institution, National Museum of Natural History, Washington, District of Columbia, USA. 


\section{RESULTS \\ Secondary parasitoids (hyperparasitoids) of Hypogeococcus spp. in Argentina and Paraguay}

Chartocerus argentinus (Brèthes, 1913), stat. rev. (Signiphoridae) (Figs. 1-12)

Signiphora argentina Brèthes 1913: 97. Type locality: not indicated in the original description but it had to be General Urquiza (Villa Urquiza), Autonomous City of Buenos Aires, Argentina because it was taken together with the syntype series of Paranusia bifasciata Brèthes (Encyrtidae) [now Anagyrus bifasciatus (Brèthes)] (Triapitsyn et al., 2014b). Stat. rev. from the previous synonymy with Chartocerus niger (Ashmead) [as Thysanus niger (Ashmead)] by De Santis 1957: 113-114.

Thysanus niger (Ashmead): De Santis 1957: 113-114 (synonymy; misidentified).

Material examined.-ARGENTINA: Salta, roadside of Ruta 9 (km 1515), S of General Güemes, $25.071400^{\circ} \mathrm{S} 65.002092^{\circ} \mathrm{W}, 831 \mathrm{~m}, 26.1 i .2019$, M. B. Aguirre, S. D. Hight, G. A. Logarzo, from Hypogeococcus sp. on Cleistocactus baumannii (Lem.) Lem. (Cactaceae) [2 females, 1 male, UCRC]. Tucumán, near Toma del Río Vipos, $26.495753^{\circ} \mathrm{S}$ 65.393003 W, 850 m, 26.ii.2019, M. B. Aguirre, S. D. Hight, G. A. Logarzo, from Hypogeococcus sp. on Cleistocactus baumannii [2 females, 3 males, IMLA, UCRC].

Redescription (specimens from Tucumán, Argentina).- Female. Body length of point-mounted, critical point dried specimens $0.79-0.825 \mathrm{~mm}$. Body (Fig. 1) shining black (gaster sometimes dark brown); antenna dark brown; fore wing with a conspicuous transverse brown band behind marginal vein and a fainter band in the widest part of wing, a narrow, hyaline band between them, and with apex almost hyaline; hind wing hyaline; legs dark brown to black except tarsi light brown. Head (Fig. 2) a little wider than high; mandible 2-dentate. Antenna (Fig. 3) with scape (minus short radicle) $4.9 \times$ as long as wide, pedicel $2.5 \times$ as long as wide, distal anellus the largest of four anelli, clava $4.9 \times$ as long as wide. Mesosoma notably shorter than metasoma (Fig. 2); mesoscutum about $1.8 \times$ as long as wide. Fore wing (Fig. 4) $2.5 \times$ as long as wide, longest marginal seta about $0.25 \times$ maximum wing width; strong setae on venation rather short; disc bare (discal seta absent). Hind wing (Fig. 5) $3.5 \times$ as long as wide, longest marginal seta $0.4 \times$ maximum wing width; disc bare (except for a discal seta). Mesofemur with 4 strong spines. Ovipositor occupying almost entire length of mesosoma, exserted slightly beyond gastral apex (by about 0.11 total ovipositor length), $2.6 \times$ length of mesotibia.

Description (specimens from Tucumán, Argentina).- Male. Body length of pointmounted, critical point dried specimens $0.66-0.79 \mathrm{~mm}$. Color of body (Fig. 6) as in female; fore wing with only one conspicuous transverse brown band behind marginal vein, remainder of disc almost hyaline. Antenna (Fig. 8) with scape (minus short radicle) $3.6 \times$ as long as wide, pedicel $1.4 \times$ as long as wide, only 2 anelli present, clava $5.1 \times$ as long as wide. Fore wing (Fig. 9) $2.5 \times$ as long as wide. Hind wing $3.9 \times$ as long as wide. Genitalia (Fig. 8) length $0.127 \mathrm{~mm}$. 


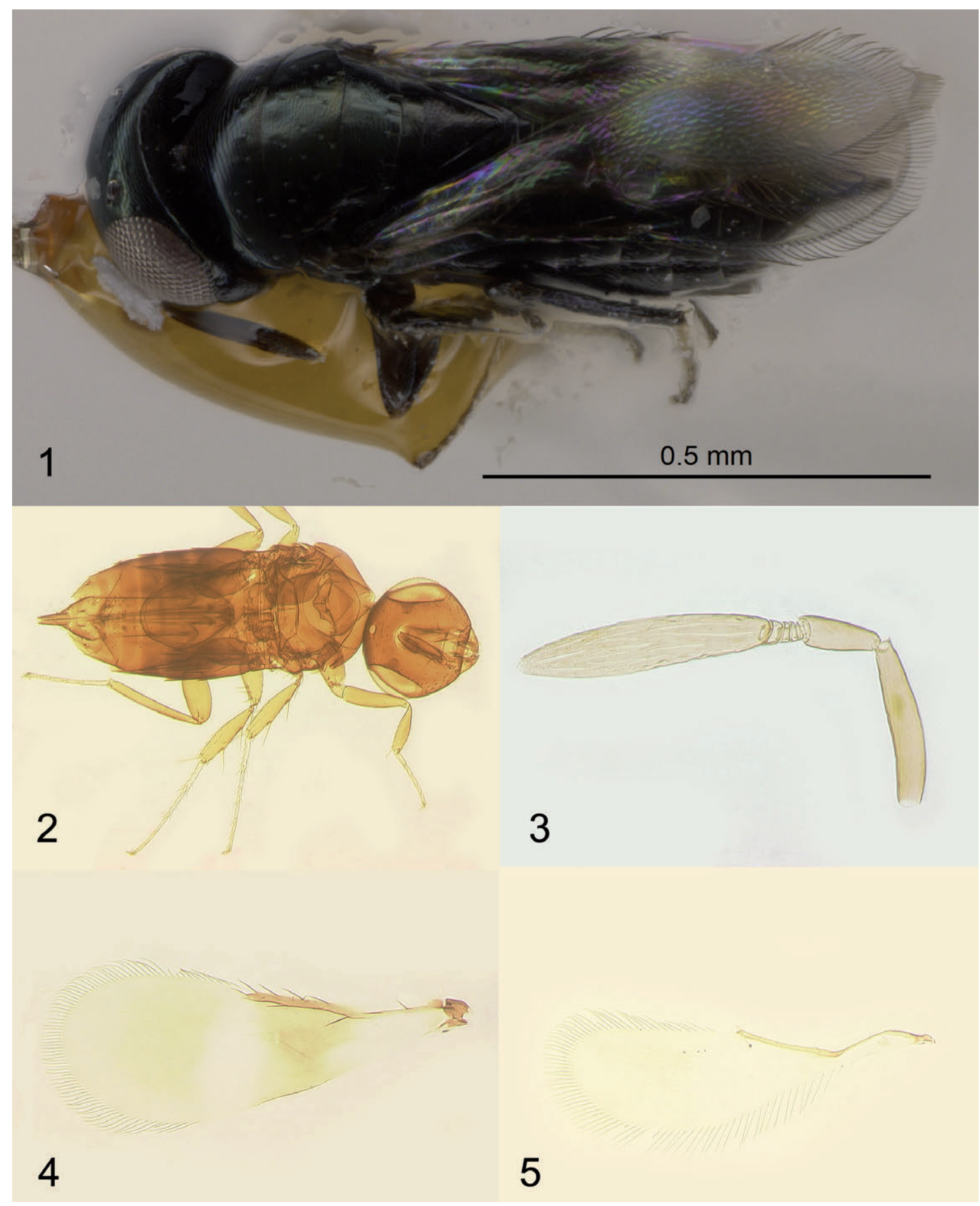

Figures 1-5. Chartocerus argentinus (Brèthes), female $\left(26.495753^{\circ} \mathrm{S} 65.393003^{\circ} \mathrm{W}\right.$, near Toma del Río Vipos, Tucumán, Argentina). (1) Habitus (dry-mounted specimen); (2) Body; (3) Antenna; (4) Fore wing; (5) Hind wing.

Distribution.- Argentina: Autonomous City of Buenos Aires and Tucumán (new record).

Hosts. - A hyperparasitoid of a Dactylopius sp. (Hemiptera: Dactylopiidae) via the primary parasitoid Anagyrus bifasciatus (Brèthes) [as Paranusia bifasciata Brèthes] (Hymenoptera: Encyrtidae) in Argentina (Brèthes, 1913). Also, a hyperparasitoid 
of a Hypogeococcus sp. on Cleistocactus baumannii via the primary parasitoid Anagyrus lapachosus (new record) whose host associations and biology are well known (Triapitsyn et al., 2016; Aguirre et al., 2019); from the same sample collected at $26.495753^{\circ} \mathrm{S}$ $65.393003^{\circ} \mathrm{W}$, near Toma del Río Vipos, Tucumán Province, 3 females and 2 males (specimens in UCRC) of this encyrtid also emerged. Likewise, from the same sample collected at $25.071400^{\circ} \mathrm{S} 65.002092^{\circ} \mathrm{W}$, S of General Güemes, Salta, 2 females (specimens in UCRC) of $A$. lapachosus also emerged.

Remarks.- Signiphora argentina Brèthes was briefly described, without providing any illustrations, by Brèthes (1913). De Santis (1957) synonymized Signiphora argentina with Thysanus niger (Ashmead) based on examination of its two "cotype" females in MACN, labeled as such by J. Brèthes himself; we agree that these are syntypes of Signiphora argentina even though Brèthes (1913: 97) mentioned apparently only one specimen as type ("tipo") despite finding several specimens of this species: "He encontrado varios ejemplares de este diminuto himenóptero, cuyo tipo incluyo en las colecciones del Museo Nacional". However, none of the four specimens of the type series of Signiphora argentina, which are very poorly mounted on three slides in MACN (A. Roig-Alsina, personal communication), is marked as such. Therefore, in order to avoid the existing ambiguity regarding status of the type specimens of this taxon and to clarify its taxonomic identity, we hereby designate a female specimen with the best preserved fore wing (with parts of head and some other appendages detached and crushed), mounted below the edge of a broken coverslip (Fig. 10, indicated by an arrow) on the slide labeled "Signiphora argentina Brèthes 179 [in pencil]" and "S15" (Fig. 10), which agrees the most with the original description, as a lectotype of Signiphora argentina Brèthes. The following red label has been added to the original ones: "Signiphora argentina Brèthes LECTOTYPE $९$ Des. by S. Triapitsyn 2019 [=Chartocerus argentinus (Brèthes)]. The other specimens on these slides are paralectotypes, as follows: 1 incomplete female on the same slide with the lectotype; 1 incomplete, dissected female on slide labeled "Signiphora argentina $\mathrm{Br}$. 178 [in pencil] 10488" and "S14" [an entry in the old registry book at MACN for this specimen is "Buenos Aires, setiembre 12, 1912; Signiphora argentina; leg. Juan Brèthes" (A. Roig-Alsina, personal communication)]; and 1 incomplete, crushed female on slide labeled "Signiphora argentina $\mathrm{Br} 180$ [in pencil]" and "S16". This taxon is also reinstated herein as a valid species, Chartocerus argentinus (Brèthes) stat. rev., from the previous synonymy with Chartocerus niger (Ashmead), because its female fore wing (Figs. 11-12) has 2 distinct, transverse, wide brown areas (the apical band is notably lighter than the basal one) and a narrow, hyaline, transverse band between them, as also specified by Brèthes (1913); the fore wing disc also has a narrow, almost hyaline band at apex. In Ch. niger, female fore wing disc is hyaline beyond the apex of venation (Figs 6a, 6b, p. 378 and 7b, p. 379 in Triapitsyn et al., 2020). Chartocerus argentinus does not fit in any other known, described species of Chartocerus from the New World either; its female fore wing (Figs. 11-12) differs from that of Ch. elongatus (Girault), which also has two wide, dark, transverse areas (http://www.usnmhymtypes.com/ default.asp?Action $=$ Show_TypesandSingle_Type $=$ TrueandTypeID $=7250$ ), in being notably wider, with a somewhat narrower hyaline band between the two dark areas, 


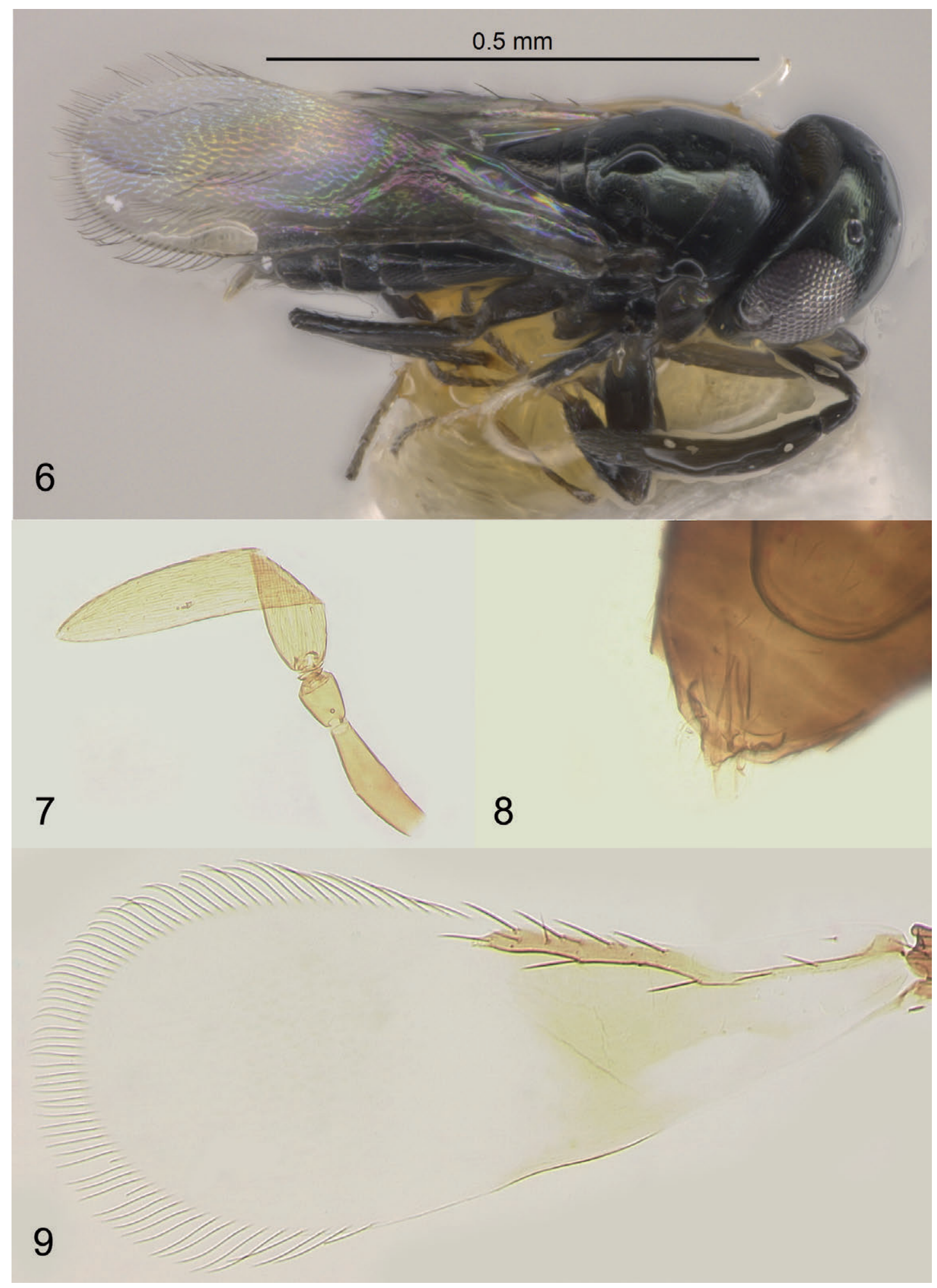

Figures 6-9. Chartocerus argentinus (Brèthes), male $\left(26.495753^{\circ} \mathrm{S} 65.393003^{\circ} \mathrm{W}\right.$, near Toma del Río Vipos, Tucumán, Argentina). (6) Habitus (dry-mounted specimen); (7) Antenna; (8) Genitalia; (9) Fore wing. 
and also in having relatively much shorter marginal setae at its apex. Designation of the allotype male of Signiphora nigra [as Thysanus niger (Ashmead)] by De Santis (1957) based on the specimen from La Plata, Buenos Aires Province, Argentina was invalid because it was not a part of the original material of Ashmead (1900). Moreover, those specimens from La Plata were without any doubt misidentified by L. De Santis: a female in USNM on slide, labeled: 1. "EVA PERON (Pcia. De Bs As) Col: Balcedo 21/X/1953 Argentina Signiphoridae", 2. "Thysanus niger (Ashmead) Det. De Santis MUSEO DE LA PLATA", 3. "DeS48" clearly belongs to Chartocerus dactylopii (Ashmead) in having a dark band in the middle of the fore wing which is characteristic of that species.

\section{Chartocerus axillaris De Santis, 1973 (Signiphoridae)}

Chartocerus (Xana) axillaris De Santis 1973: 152-153. Type locality: Chacras de Coria, Mendoza, Argentina.

Chartocerus axillaris De Santis: De Santis 1979: 253 (catalog); Triapitsyn et al. 2018: 425-426 (taxonomic history, distribution in Argentina, host associations, comments).

Chartocerus ?axillaris De Santis: Triapitsyn et al. 2014a: 176-178 (distribution in Argentina, taxonomic and other comments), 180-183 (illustrations).

Material examined.- ARGENTINA: Mendoza, roadside of Ruta $52 \mathrm{~N}$ of Hornito del Gringo, $32.7074^{\circ} \mathrm{S} 68.8561^{\circ} \mathrm{W}, 816 \mathrm{~m}, 26 . i i i .2017, \mathrm{M}$. B. Aguirre, G. A. Logarzo, S. D. Hight, S. V. Triapitsyn, emerged 28.iii-10.iv.2017 from Hypogeococcus festerianus Lizer and Trelles on Cereus aethiops Haw. [6 females, 5 males, UCRC].

Other material examined.- ARGENTINA: Mendoza: Departamento Rivadavia, Distrito Medrano, Calle La Legua, Finca Viciana S.A., 22.ii.2007, S. J. Lanati, from Planococcus ficus (Signoret) via Anagyrus pseudococci (Girault) on Malbec wine grape clusters, Vitis vinifera L. [1 female, 1 male, UCRC]. Departamento Tunuyán, near Tunuyán, at Ruta 40, 8.ii.2007, S. J. Lanati, from Planococcus ficus via Anagyrus pseudococci on grape clusters, Vitis vinifera cultivar alba [5 females, UCRC].

Distribution.- Argentina (Catamarca, Córdoba, Mendoza, Salta) (Triapitsyn et al., 2018), and Paraguay (De Santis, 1979).

Hosts.- Hyperparasitoid of Hypogeococcus festerianus Lizer and Trelles on Cereus aethiops (Cactaceae) via the primary parasitoid Anagyrus cachamai, Hypogeococcus pungens Granara de Willink sensu stricto, as defined by Poveda-Martínez et al. (2019), and Hypogeococcus spp. (Triapitsyn et al., 2014a; Triapitsyn et al., 2018), and also of a Pseudococcus sp. (Pseudococcidae) on Solanum elaeagnifolium Cav. (Solanaceae) via the primary parasitoid Anagyrus lopezi (De Santis) (De Santis, 1973), as well as of Planococcus ficus (Signoret) (Pseudococcidae) on Vitis vinifera (Vitaceae) via the primary parasitoid Anagyrus pseudococci (Girault). 


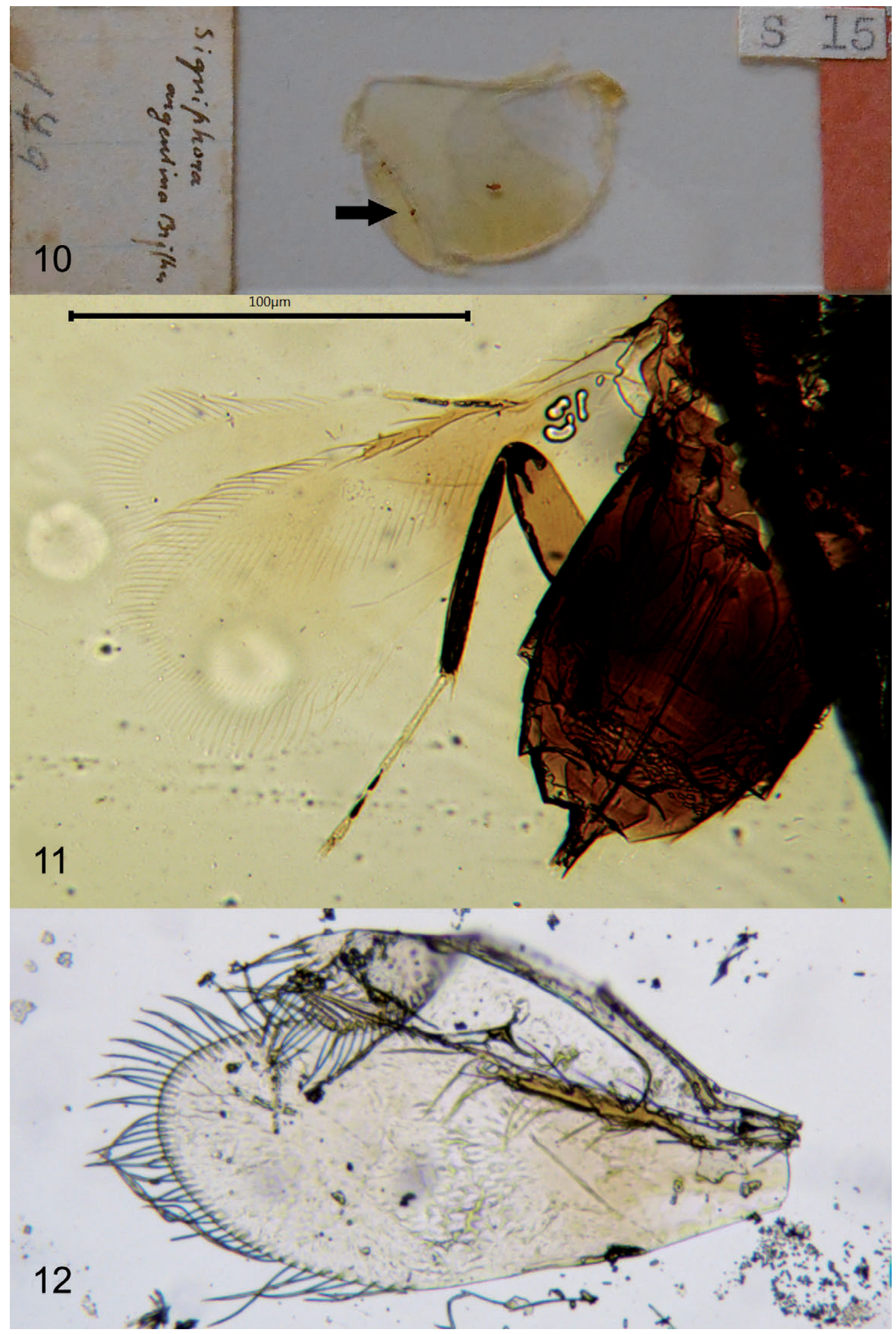

Figures 10-12. Chartocerus argentinus (Brèthes), female. (10) Lectotype/paralectotype slide of Signiphora argentina (arrow indicates the lectotype); (11) Fore and hind wings (lectotype of Signiphora argentina); (12) Fore and hind wings (paralectotype of Signiphora argentina, slide S14). 
Remarks.- Only one primary parasitoid of Hypogeococcus festerianus, Anagyrus cachamai (3 females, 4 males in UCRC), emerged from the same sample with Chartocerus axillaris collected at $32.7074^{\circ} \mathrm{S} 68.8561^{\circ} \mathrm{W}$, at roadside of Ruta $52 \mathrm{~N}$ of Hornito del Gringo, Mendoza Province. Further 3 females, 4 males of $A$. cachamai (specimens in UCRC) were reared from the same host at the same locality on 25.v.2018 by M. B. Aguirre, G. A. Logarzo and S. D. Hight.

Cheiloneurus sp. (Encyrtidae) (Figs. 13-16)

Material examined.- PARAGUAY: Presidente Hayes, Roadside of Ruta 9, Colonia San Miguel, 2.v.2019, M. B. Aguirre, S. D. Hight, G. A. Logarzo, from Hypogeococcus pungens Granara de Willink on Amaranthaceae [1 female, IBNP].

Diagnosis.- Body length of point-mounted, critical point dried specimen prior to slide-mounting $0.89 \mathrm{~mm}$. Body (Fig. 13) mostly light brown except mesoscutum posteriorly brown with metallic luster, propodeum dark brown, and gaster brown (hypopygium light brown); antenna mostly light brown except apex of sixth funicular segment and clava brown; fore wing disc strongly infuscate from behind marginal vein to wing's apex, with two small, lighter areas, one just beyond venation and the other behind apex of venation at wing's posterior margin; hind wing hyaline; legs mostly light brown except procoxa and base of mesotibia white. Frontovertex moderately reticulate; scape with inconspicuous sculpture; pronotum, scutellum, axillae and scutellum with conspicuous, mostly longitudinal, cell-like sculpture. Head slightly higher than wide. Frontovertex $0.43 \times$ head width at level of anterior ocellus. Ocelli forming a slightly obtuse triangle, posterior ocellus about its own diameter distance from eye margin. Antenna (Fig. 15) with scape minus radicle $4.7 \times$ as long as broad, widest in the middle. Pedicel $1.7 \times$ as long as wide, longer than any funicular segment (hereafter abbreviated as F). F1 a little, but distinctly longer than wide, F2 subquadrate, F3 and F4 slightly wider than long; F5 and F6 about as long as wide and notably larger than other funicular segments (F6 slightly longer and wider than F5); multiporous plate sensilla only on F5 (2) and F6 (3). Clava $2.75 \times$ as long as wide. Mesosoma shorter than gaster (Fig. 14). Pronotum with dark setae, mesoscutum with dense silverly pubescence; mesoscutum about as long as scutellum; a tuft of long, dark setae on scutellum present (Figs. 13-14). Wings not abbreviated, fore wing extending slightly beyond apex of gaster. Fore wing (Fig. 16) narrow, $3.4 \times$ as long as wide; postmarginal vein with a long, strong apical seta and shorter than stigmal vein; filum spinosum with 2 rows of strong setae, linea calva open posteriorly; longest marginal seta $0.23 \times$ maximum wing width. Hind wing $5.4 \times$ as long as wide; longest marginal seta $0.44 \times$ maximum wing width. Mesobasitarsus much shorter than mesotibial spur (as 5:9). Ovipositor occupying almost the entire length of gaster, slightly exserted beyond gastral apex (by $0.08 \times$ own length), $1.7 \times$ length of mesotibia. 

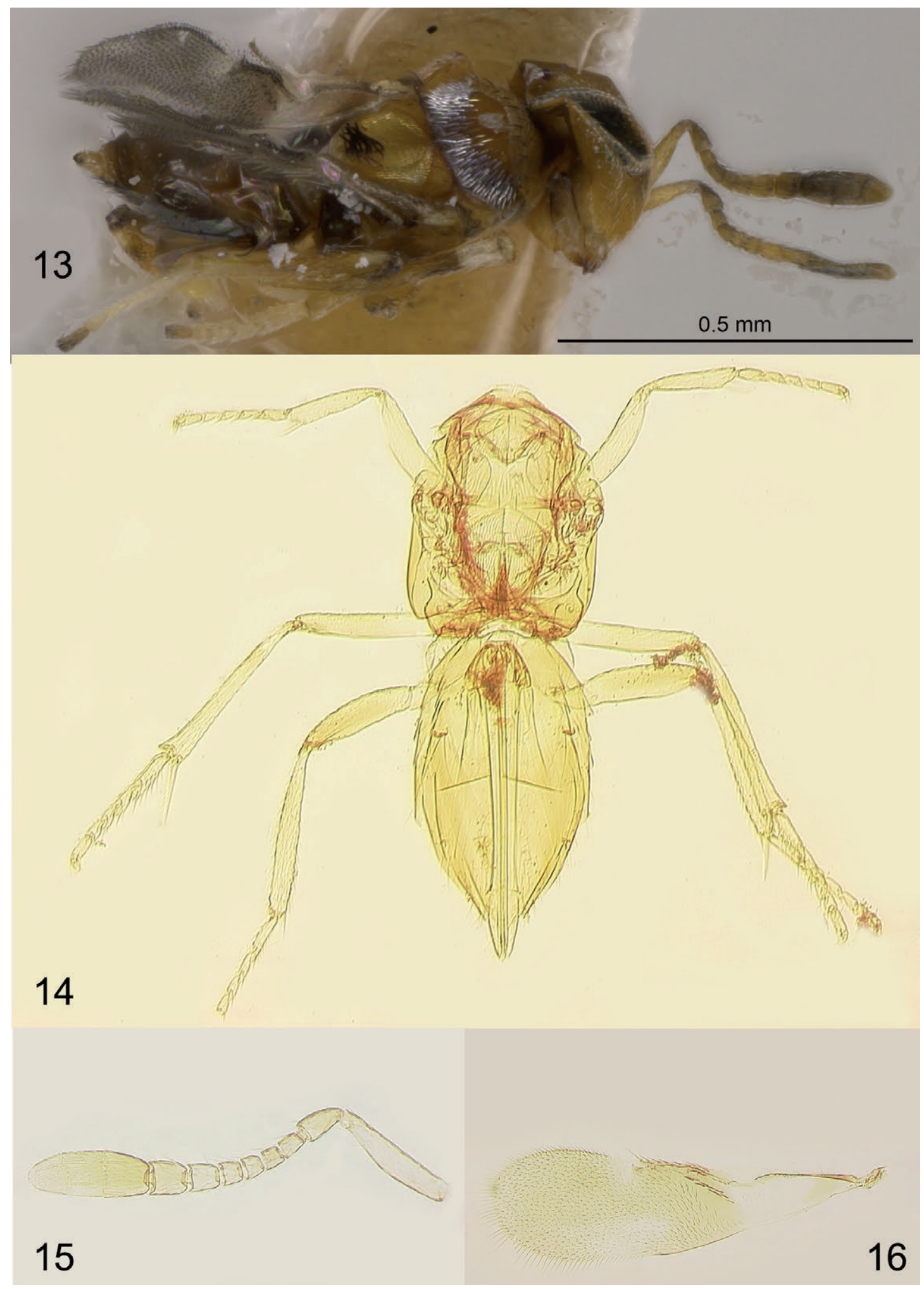

Figures 13-16. Cheiloneurus sp., female (Colonia San Miguel, Presidente Hayes, Paraguay). (13) Habitus (dry-mounted specimen prior to slide-mounting); (14) Mesosoma, metasoma, and legs; (15) Antenna; (16) Fore wing. 
Distribution.- Paraguay.

Host.- A hyperparasitoid of Hypogeococcus pungens Granara de Willink sensu stricto, as defined by Poveda-Martínez et al. (2019), on an unknown plant belonging to the family Amaranthaceae, via an encyrtid primary parasitoid. From the same sample and collecting event, two species of Encyrtidae, both primary parasitoids of this host, were reared: Anagyrus cachamai (12 females, 11 males, IBNP, UCRC) and Leptomastidea hypogeococci Triapitsyn (5 females, 2 males, IBNP, UCRC). For the latter species Paraguay is a new country distribution record; its known range was indicated by Triapitsyn et al. (2018).

Remarks.- It is presumably a new species, which does not key to any of the described species of Cheiloneurus Westwood from the New World in Triapitsyn et al. (2020). It is not described here because only one specimen is available and also because its identity is not entirely clear. Morphologically, among the New World congeneric species, female of this Cheiloneurus sp. is most similar to Ch. cushmani Crawford, known from the USA (Noyes, 2019), from which it differs in having a lighter colored body (Fig. 13), F2 almost quadrate and slightly shorter than F1 (Fig. 15), and the fore wing dark at apex (Fig. 16). In Ch. cushmani, F2 is longer than wide and longer than F1, and the fore wing is lighter, almost hyaline at apex. This specimen from Paraguay is very similar to the Old World species Ch. quadricolor (Girault), redescribed and illustrated by Guerrieri and Viggiani (2005), which is not known to occur in the New World. A molecular comparison between them would be necessary to test its possible conspecificity, which biogeographically would be unlikely, also considering their very different host associations $(H$. pungens does not occur in the Old World).

\section{Prochiloneurus argentinensis (De Santis, 1964) (Encyrtidae)}

Achrysopophagus argentinensis De Santis 1964: 357-359. Type locality: San Javier, Tucumán, Argentina.

Prochiloneurus sp.: Triapitsyn et al. 2014a: 178 (female from El Portezuelo, Catamarca, Argentina), 184 (illustration).

Prochiloneurus argentinensis (De Santis): Löhr et al. 1990: 423 (list of hyperparasitoids); Noyes and Triapitsyn 2018: 14-15 (mentioned), 18 (illustrations of the female from Catamarca, Argentina), 19 (illustrations of the holotype), 21 (mentioned), 22-25 (resurrection as a valid taxon from the previous synonymy under Prochiloneurus dactylopii (Howard), taxonomic history, redescription, diagnosis, distribution, host associations), 34 (mentioned); Triapitsyn et al. 2018: 428-430 (taxonomic history, distribution in Argentina, description and illustrations of the male, host associations).

Distribution.- - Argentina (Catamarca, Córdoba, Misiones, Tucumán), Brazil, and Guyana (Triapitsyn et al., 2018). 
Hosts.- A hyperparasitoid of Hypogeococcus pungens Granara de Willink sensu stricto, as defined by Poveda-Martínez et al. (2019), on Alternanthera pungens Kunth (Amaranthaceae), probably via an Anagyrus sp. primary parasitoid, and also of Hypogeococcus sp. (likely via Anagyrus quilmes Triapitsyn, Logarzo and Aguirre primary parasitoid), as well as of Phenacoccus herreni Cox and Williams (Pseudococcidae) (Triapitsyn et al., 2018).

\section{Taxonomic notes on a hyperparasitoid newly recorded from Paraguay}

Ablerus platensis (Brèthes), 1914 (Azotidae) (Fig. 17)

Dimacrocerus platensis Brèthes 1914: 5-7. Type locality: Buenos Aires, Argentina (De Santis 1948).

Azotus platensis (Brèthes): García Mercet 1922: 197 (list); De Santis 1948: 214 (key), 215-219 (type information, redescription, illustration, distribution, host associations).

Ablerus platensis (Brèthes): Noyes 2019 (online database).

Material examined-PARAGUAY: Presidente Hayes, roadside of Ruta 9, 23.63839 ${ }^{\circ} \mathrm{S}$ $58.70143^{\circ}$ W, 101 m, 2.v.2019, M. B. Aguirre, S. D. Hight, G. A. Logarzo, on Harrisia bonplandii (Parm.) Britton and Rose infested with Hypogeococcus sp. and unidentified Diaspididae [1 female, IBNP].

Distribution.- Argentina: Buenos Aires (Brèthes 1914 [as Dimacrocerus platensis]; De Santis 1948 [as Azotus platensis]) and Tucumán (Terán et al. 1985 [as Azotus platensis]), and Paraguay (new record), as well as Brazil, Chile, and Uruguay (Noyes 2019).

Hosts.- Diaspididae (Hemiptera): Pseudaulacaspis pentagona (Targioni Tozzetti) in Buenos Aires, Argentina (Brèthes 1914 [as Dimacrocerus platensis of Diaspis pentagona]; De Santis 1948 [as Azotus platensis]), Aonidiella aurantii (Maskell) on Citrus sp. (Rutaceae) in Tucumán, Argentina (Terán et al. 1985 [as Azotus platensis]), and of Chrysomphalus dictyospermi (Morgan) in Buenos Aires Province, Argentina (De Santis, 1967 [as Azotus platensis]).

Ablerus platensis could also be a hyperparasitoid of Hypogeococcus sp. on Harrisia bonplandii via Anagyrus cachamai in Paraguay, but we are not sure about this host association because some armored scales were also present on that cactus plant; all other herbivorous hosts associated with this hyperparasitoid belong to Diaspididae (Noyes, 2019).

Remarks.- This specimen (Fig. 17) is perhaps more tentatively than positively identified as $A$. platensis because its pedicel is somewhat differently colored, being dark basally and white apically, whereas De Santis (1948, p. 216) redescribed the pedicel in the female of this species as yellowish-white ("blanco-amarillento"). That perhaps was due to the fact that the only known female from the original type series 


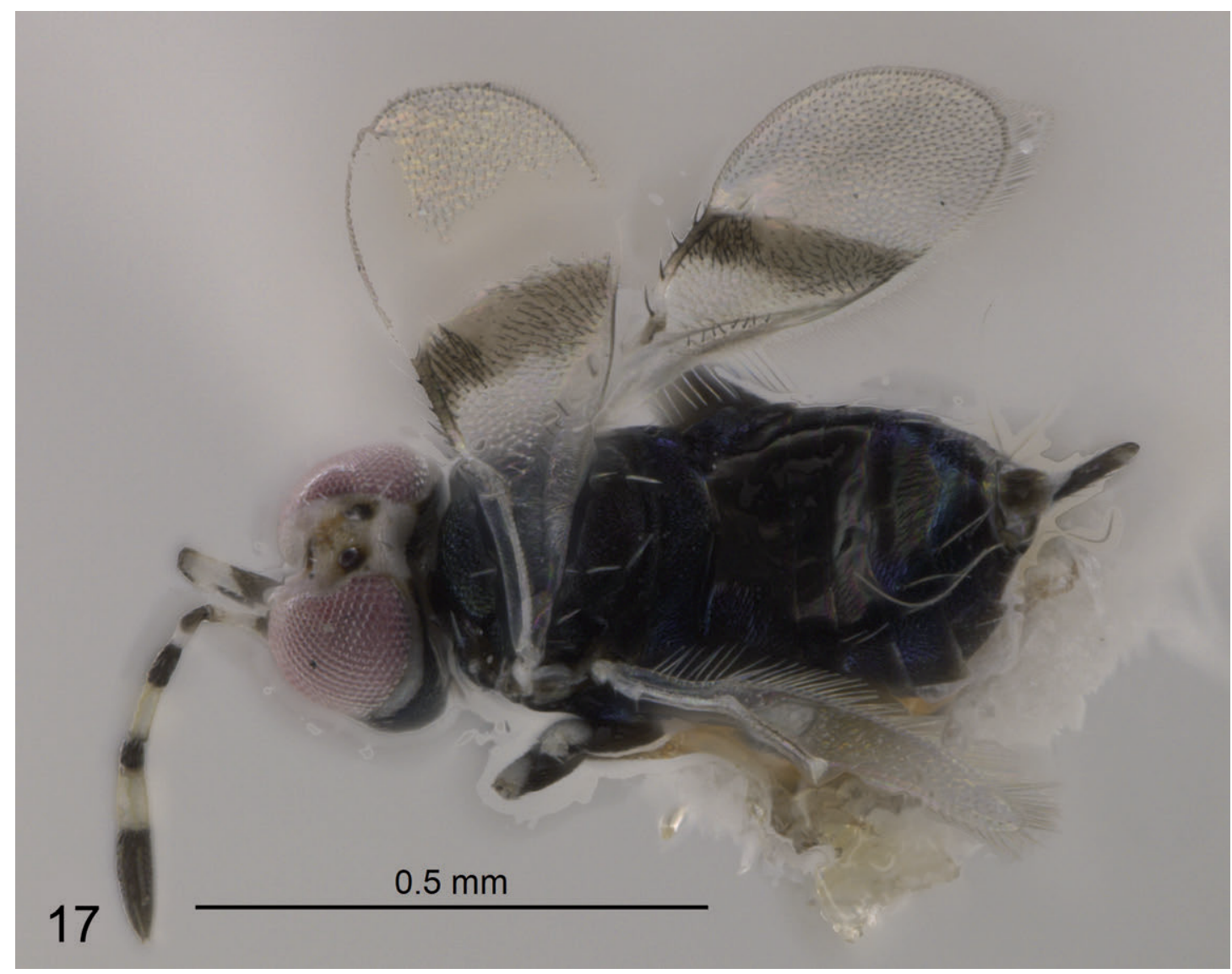

Figure 17. Ablerus platensis (Brèthes), female $\left(23.63839^{\circ} \mathrm{S} 58.70143^{\circ} \mathrm{W}\right.$, Presidente Hayes, Paraguay). Habitus.

was poorly mounted on a slide. Brèthes (1914) also described (p. 5) and illustrated (p. 6) the pedicel of the female antenna as being white. He did not provide any data on the type specimens of both sexes, so these were all syntypes. De Santis (1948, p. 219) mentioned one female and two males from the original Brèthes' material, only incorrectly calling (p. 218) one of the males "el alotipo" (the allotype), which was an invalid designation. We hereby designate the only known syntype female in MACN, originally labeled "Dimacrocerus platensis" (De Santis, 1948, p. 219), as a lectotype of Dimacrocerus platensis Brèthes, to avoid the existing confusion about the type specimens of this taxon. The following red label has been added to the original one: "Dimacrocerus platensis Brèthes, 1914 LECTOTYPE $९$ Des. by S. V. Triapitsyn 2020 [= Ablerus platensis (Brèthes)]”.

\section{ACKNOWLEDGMENTS}

We thank Vladimir V. Berezovskiy (UCRC) for mounting specimens, Anamaria Dal Molin (Coleção Entomológica Adalberto A. Varela-Freire, Departamento de Microbiologia e Parasitologia, Centro de Biociências, Universidade Federal do Rio Grande do Norte, Natal, Rio Grande do Norte, Brazil) for valuable consultations 
on Chartocerus taxonomy, Arturo Roig-Alsina (MACN) for providing information on the syntypes of Signiphora argentina and also their digital images, James B. Woolley (Texas AandM University, College Station, Texas, USA) for giving access to the loaned specimens of Signiphoridae (from USNM) at his laboratory, Silvio Lanati (INTA - Estación Experimental Agropecuaria La Consulta, La Consulta, Mendoza, Argentina) for sending interesting specimens for identification, and Daniel A. Aquino (Centro de Estudios Parasitológicos y de Vectores, CONICET - UNLP, La Plata, Buenos Aires, Argentina) for help with a reference.

\section{FUNDING}

This study was supported by the USDA-APHIS Farm Bill funding for Fiscal Years 2017 and 2019 and APHIS-Biological Control support funding throughout the survey period.

\section{AUTHOR CONTRIBUTIONS}

Serguei V. Triapitsyn wrote the manuscript, identified specimens, and did all taxonomic work; María B. Aguirre, Guillermo A. Logarzo and Stephen D. Hight contributed to the manuscript and reviewed it; Guillermo A. Logarzo and Stephen D. Hight were responsible for funding acquisition; and Serguei V. Triapitsyn, María B. Aguirre, Guillermo A. Logarzo and Stephen D. Hight conducted surveys and collected material.

\section{COMPETING INTERESTS}

The authors have declared that no competing interests exist.

\section{LITERATURE CITED}

Aguirre, M. B., Logarzo, G. A., Triapitsyn, S. V., Diaz-Soltero, H., Hight, S. D., Bruzzone, O. A. (2019). Analysis of biological traits of Anagyrus cachamai and Anagyrus lapachosus to assess their potential as biological control candidate agents against Harrisia cactus mealybug pest in Puerto Rico. BioControl, 64, 539-551.

Ashmead, W. H. (1900). On the genera of chalcid-flies belonging to the subfamily Encyrtinae. Proceedings of the United States National Museum, 22, 323-412.

Brèthes, J. (1913). Himenópteros de la América meridional. Anales del Museo Nacional de Historia Natural de Buenos Aires, 24, 35-165.

Brèthes, J. (1914). I.-Les ennemis de la "Diaspis pentagona" dans la République Argentine. Nunquam Otiosus (Buenos Aires), 1, 1-16. 
De Santis, L. (1948). Estudio monográfico de los afelínidos de la República Argentina (Hymenoptera, Chalcidoidea). Revista del Museo de La Plata (Nueva serie), Sección Zoología, 5, 23-280.

De Santis, L. (1957). Anotaciones sobre calcidoideos Argentinos (Hymenoptera). Notas del Museo de La Plata, Buenos Aires (Zoología), 19, 107-119.

De Santis, L. 1964 (1963). Encírtidos de la República Argentina (Hymenoptera: Chalcidoidea). Anales de la Comisión de Investigación Científica de la Gobernación de la Provincia de Buenos Aires, 4, 9-422.

De Santis, L. (1967). Catálogo de los himenópteros argentinos de la serie Parasítica, incluyendo Bethyloidea. Comisión de Investigación Científica, Gobernación de la provincia de Buenos Aires, La Plata, 337 pp.

De Santis, L. (1973). Nota sobre signifóridos de la República Argentina (Hymenoptera: Chalcidoidea). Revista de la Facultad de Agronomía, Universidad Nacional de La Plata, 49, 143-153.

De Santis, L. (1979). Catálogo de los himenópteros calcidoideos de América al sur de los Estados Unidos. Publicación especial, Comisión de Investigaciones Científicas de la provincia de Buenos Aires, La Plata, 488 pp.

García Mercet, R. (1922). El género Azotus Howard (Him. Calcídidos). Boletín de la Real Sociedad Española de Historia Natural, 22, 196-200.

Guerrieri, E., Viggiani, G. (2005). A review of the encyrtid (Hymenoptera: Chalcidoidea) parasitoids of Dryinidae (Hymenoptera: Chrysidoidea) with description of a new species of Cheiloneurus. Systematics and Biodiversity, 2, 305-317.

Löhr, B., Varela, A. M., Santos, B. (1990). Exploration for natural enemies of the cassava mealybug, Phenococcus manihoti (Homoptera: Pseudococcidae), in South America for the biological control of this introduced pest in Africa. Bulletin of Entomological Research, 80, 417-425.

Noyes, J. S. (2019). Universal Chalcidoidea database. The Natural History Museum, London. http://www.nhm.ac.uk/chalcidoids. Accessed 10 June 2020.

Noyes, J. S., Triapitsyn, S. V. (2018). Taxonomic notes on some New World Prochiloneurus Silvestri (Hymenoptera: Encyrtidae) with description of a new species, a hyperparasitoid of Hypogeococcus sp. (Hemiptera: Pseudococcidae) in Barbados and Puerto Rico. In: Santhosh S., Nasser M., Sudheer K. (Eds.), Insect diversity and taxonomy. T. C. Narendran Commemorative Volume, Prof. T. C. Narendran Trust for Animal Taxonomy, Calicut, India, pp. 13-37.

Poveda-Martínez, D., Aguirre, M. B., Logarzo, G., Calderón, L., de la Colina, A., Hight, S., Triapitsyn, S., Diaz-Soltero, H., Hasson, E. (2019). Untangling the Hypogeococcus pungens species complex (Hemiptera: Pseudococcidae) for Argentina, Australia, and Puerto Rico based on host plant associations and genetic evidence. PLoS One, 14: e0220366 (https://doi.org/10.1371/journal.pone.0220366).

Poveda-Martínez, D., Aguirre, M. B., Logarzo, G., Hight, S. D., Triapitsyn, S., DiazSoltero, H., Vitorino, M. D., Hasson, E. (2020). Species complex diversification by host plant use in an herbivorous insect: The source of Puerto Rican cactus mealybug pest and implications for biological control. Ecology and Evolution, 10 (19): 10463-10480 (https://doi.org/10.1002/ece3.6702). 
Terán, A. L., Collado de Manes, M. L., Glencross, S., Lázaro, H., Álvarez, R. (1985). Parasitoides primarios y secundarios de la "cochinilla roja australiana", Aonidiella aurantii (Mask.) (Homoptera: Coccoidea: Diaspididae) en plantaciones cítricas de Tucumán, República Argentina. Primary and secondary parasites of the California red scale Aonidiella aurantii (Mask.) (Homoptera: Coccoidea: Diaspididae) in citrus orchards of Tucumán, Argentina. Revista de Investigación, Centro de Investigaciones para la Regulación de Poblaciones de Organismos Nocivos, Argentina, 3, 7-14.

Tougeron, K., Tena, A. (2019). Hyperparasitoids as new targets in biological control in a global change context. Biological Control, 130, 164-171.

Triapitsyn, S. V., Aguirre, M. B., Logarzo, G. A. (2016). A new Anagyrus (Hymenoptera: Encyrtidae) from Argentina, parasitoid of Hypogeococcus sp. (Hemiptera: Pseudococcidae) on Harrisia pomanensis (Cactaceae). Zootaxa, 4114, 590-594.

Triapitsyn, S. V., Aguirre, M. B., Logarzo, G. A., Dal Molin, A. (2014a). Taxonomic notes on primary and secondary parasitoids (Hymenoptera: Encyrtidae and Signiphoridae) of Hypogeococcus spp. (Hemiptera: Pseudococcidae) in Argentina. Acta Zoológica Lilloana, 58, 171-186.

Triapitsyn, S. V., Logarzo, G. A., Aguirre, M. B., Aquino, D. A. (2014b). Two new species of Anagyrus (Hymenoptera: Encyrtidae) from Argentina, parasitoids of Hypogeococcus spp. (Hemiptera: Pseudococcidae), with taxonomic notes on some congeneric taxa. Zootaxa, 3861, 201-230.

Triapitsyn, S. V., Aguirre, M. B., Logarzo, G. A., Hight, S. D., Ciomperlik, M. A., Rugman-Jones, P. F., Verle Rodrigues, J. C. (2018). Complex of primary and secondary parasitoids (Hymenoptera: Encyrtidae and Signiphoridae) of $\mathrm{Hy}$ pogeoccoccus spp. mealybugs (Hemiptera: Pseudococcidae) in the New World. Florida Entomologist, 101, 411-434.

Triapitsyn, S. V., Hight, S. D., Logarzo, G. A., Aguirre, M. B., Verle Rodrigues, J. C., Trjapitzin, V. A., Rivera Ocasio, Z., Rivera-Vázquez, M. L., West Ortiz, M. J., Rodríguez Reyes, Y. (2020). Natural enemies of the Harrisia cactus mealybug and other Hypogeococcus species (Hemiptera: Pseudococcidae) in Puerto Rico: Identification and taxonomic notes on primary and secondary parasitoids. Neotropical Entomology, 49, 369-391. 